\title{
Minimasi Kelebihan dan Kekurangan Berat pada Proses Pengisian Tepung Bumbu Kemasan 40 Gram
}

\author{
Andira Taslim ${ }^{1}$ dan Rintih Kurniawati ${ }^{2}$ \\ 1,2) Industrial Engineering Department, Faculty of Technology, President University \\ Jababeka Education Park, Jl. Ki Hajar Dewantara Kota Jababeka, Bekasi 17550, Indonesia \\ Email: ${ }^{1}$ andira@president.ac.id, ${ }^{2}$ rintihkurnia@yahoo.co.id
}

\begin{abstract}
Abstrak
Kualitas adalah penilaian terhadap produk yang sesuai dengan spesifikasi pelanggan dan berhubungan dengan tingkat kepuasan pelanggan. Kualitas merupakan salah satu faktor yang mempengaruhi daya saing suatu produk di pasar. Salah satu indikator kualitas suatu produk adalah ada tidaknya cacat (defect) dari produk yang dihasilkan. Dalam penelitian ini diterapkan metode DMAIC untuk memecahkan permasalahan pada proses pengisian tepung bumbu kemasan 40 gram pada mesin single line di PT XYZ. Penggunaan metode DMAIC bertujuan untuk menurunkan defect karena ketidakstabilan proses pengisian tepung bumbu yang menyebabkan ketidaksesuaian bobot produk dengan standar yang telah ditentukan. Tahap improve yang dilakukan meliputi setting mesin dengan mengatur jarak antara cup dan scraper pada mesin single line serta dengan menambah jumlah sampling. Sampling bobot produk yang sebelumnya hanya tiap satu jam sekali oleh operator QC, ditambah menjadi sampling setiap setengah jam sekali oleh operator produksi dan tiap satu jam sekali tetap dilakukan oleh operator QC.
\end{abstract}

Kata Kunci: kualitas, DMAIC, defect, bobot produk, sampling, setting mesin

\begin{abstract}
Quality is an assessment of products that are in accordance with customer specifications and relate to the level of customer satisfaction. Quality is one of the factors that influence the competitiveness of a product in the market. One indicator of the quality of a product is the presence or absence of defects (defects) of the products produced. In this study the DMAIC method was applied to solve the problem in the process of filling the 40 gram seasoning flour packaging on a single line machine at PT XYZ. The use of the DMAIC method aims to reduce defects due to the instability of the seasoning flour filling process which causes a mismatch of product weights to the specified standards. The improvement phase includes setting the machine by adjusting the distance between the cup and scraper on a single line machine and by increasing the number of sampling. Sampling the weight of the product that was previously only once every hour by the QC operator, added to the sampling every half hour by the production operator and once an hour is still carried out by the QC operator.
\end{abstract}

Keywords: quality, DMAIC, defect, product weight, sampling, machine settings

\section{Pendahuluan}

Kualitas merupakan salah satu faktor yang mempengaruhi daya saing suatu produk. Kualitas secara umum adalah sebuah penilaian terhadap produk yang bebas dari kesalahan produksi dan sesuai dengan spesifikasi yang dibutuhkan oleh pelanggan. Aspek dari kualitas tidak hanya berfokus pada produk, tetapi juga pada proses produksi suatu produk. Salah satu yang menjadi indikator kualitas pada suatu produk adalah cacat (defect) pada produk yang dihasilkan. Cacat atau defect dapat diartikan sebagai ketidaksesuaian suatu produk terhadap standar yang telah ditetapkan.

Untuk menghasilkan produk yang sesuai dengan standar yang telah ditetapkan diperlukan peningkatan kualitas dengan menggunakan $Q C$ tools yang tepat. Salah satu metode peningkatan kualitas yang dapat diterapkan adalah metode DMAIC (Define, Measure, Analyze, Improve and Control) dengan menggunakan alat bantu Statistical Process Control (SPC). SPC merupakan suatu teknik statistik yang digunakan secara luas untuk memastikan bahwa suatu proses memenuhi standar untuk menghasilkan suatu produk yang berkualitas.

PT XYZ merupakan salah satu perusahaan yang bergerak di bidang makanan. Salah satu produk yang dihasilkan adalah tepung bumbu. Tepung bumbu yang diproduksi oleh PT XYZ dipasarkan dalam berbagai ukuran kemasan. Salah satu kendala yang dihadapi PT XYZ dalam proses produksi tepung bumbu adalah dalam proses pengisian produk dalam kemasan. Dalam proses pengisian produk dalam 
kemasan belum stabil sehingga masih terdapat produk yang cacat (defect) karena bobot produk tidak sesuai dengan standar yang telah ditetapkan oleh perusahaan.

Salah satu produk yang memiliki tingkat cacat tinggi adalah tepung bumbu kemasan 40 gram yang dikemas di mesin single line. Bentuk cacat yang terjadi adalah bobot produk tidak sesuai dengan standar yang telah ditetapkan oleh perusahaan yang disebabkan oleh ketidakstabilan proses pengisian tepung bumbu dalam kemasan. Dari dua juta kemasan tepung bumbu 40 gram yang diproduksi per bulan diketahui rata-rata 14,3\% kemasan tidak sesuai dengan standar bobot yang telah ditentukan oleh perusahaan.

\section{Metode}

Penelitian stabilisasi proses pengisian tepung bumbu kemasan 40 gram menggunakan metode DMAIC.

\subsection{Define}

Define merupakan tahapan pertama dalam peningkatan kualitas dengan metode DMAIC. Langkah-langkah yang terdapat dalam fase define antara lain menentukan masalah, menentukan tujuan dari proyek peningkatan standar kualitas ,membuat gambaran secara keseluruhan dari proses yang akan dianalisis.

\subsection{Measure}

Measure merupakan tahapan kedua dalam peningkatan kualitas dalam metode DMAIC. Pada tahap ini dilakukan pengukuran terhadap data yang diperoleh dari tahapan sebelumnya. Tahap pengukuran ini sangat penting peranannya dalam meningkatkan kualitas, karena dapat diketahui keadaan perusahaan dari data yang ada sehingga menjadi patokan atau dasar untuk melakukan analisa dan perbaikan. Dalam Six Sigma ada dua basis pengukuran yaitu konsep pengukuran kinerja produk dan konsep pengukuran kinerja proses.

\subsection{Analyze}

Tahap analyze merupakan tahapan ketiga dalam peningkatan kualitas dengan metode DMAIC. Pada tahap ini kita perlu melakukan beberapa hal berikut ini :

a. Mengidentifikasi jenis-jenis cacat yang terjadi dan membuat prioritas cacat mana yang paling dominan pengaruhnya terhadap kualitas produk secara keseluruhan.

b. Mengumpulkan dan menganalisa berbagai akar penyebab masalah dari cacat yang dominan tersebut, ditinjau dari segi man, machine, method,environment dan material menggunakan tabel 5-Why.

c. Mencari penyebab dari daftar akar penyebab masalah yang telah dianalisa.

\subsection{Improve}

Tahap improve merupakan tahapan pengujian yang bertujuan untuk mengoptimalisasi proses dari data yang diperoleh dalam table 5-Why. Tahap improve juga mengimplementasi solusi yang telah ditetapkan untuk mengeliminasi penyebab masalah yang ada.

\subsection{Control}

Tahapan sesudah improve adalah control. Tahapan ini merupakan tahapan terakhir dalam pemecahan masalah menggunakan metode DMAIC. Dalam fase ini seluruh usaha-usaha proses peningkatan yang dilakukan dikendalikan dan seluruh usaha tersebut didokumentasikan dan disebarluaskan atau disosialisasikan ke segenap karyawan perusahaan yang bersangkutan.

\section{Hasil dan Pengamatan}

Hasil pengamatan berupa data defect ketidaksesuaian bobot produk dengan standar yang telah ditetapkan yaitu 40 sampai 43 gram. Dari hasil pengamatan diketahui defect yang terjadi pada bulan Juli 2017 sebesar 13,60\%, bulan Agustus 2017 sebesar 15,20\%, bulan September 2017 sebesar 15,80\%, dan bulan Oktober 2017 sebesar 12,60\%. 


\subsection{X-bar dan S Chart}

Peta kendali X-bar $S$ chart dibuat untuk mengetahui proses pengisian tepung bumbu kemasan 40 gram berada pada batas kendali atau tidak. Contoh perhitungan X-bar dan S Chart untuk bulan Oktober 2017.

Tabel 1. Data Bulan Oktober 2017

\begin{tabular}{|c|c|c|}
\hline Sampel & $\bar{\chi}$ & $\mathbf{S}$ \\
\hline 1 & 42,420 & 0,481 \\
\hline 2 & 42,616 & 0,644 \\
\hline 3 & 42,588 & 0,282 \\
\hline 4 & 42,416 & 0,487 \\
\hline 5 & 42,568 & 0,455 \\
\hline 6 & 42,176 & 0,417 \\
\hline 7 & 42,480 & 0,465 \\
\hline 8 & 42,116 & 0,694 \\
\hline 9 & 42,536 & 0,632 \\
\hline 10 & 42,456 & 0,402 \\
\hline 11 & 42,380 & 0,495 \\
\hline 12 & 42,548 & 0,578 \\
\hline 13 & 42,476 & 0,396 \\
\hline 14 & 42,608 & 0,523 \\
\hline 15 & 41,944 & 0,923 \\
\hline 16 & 42,308 & 0,863 \\
\hline 17 & 42,416 & 0,487 \\
\hline 18 & 42,568 & 0,455 \\
\hline 19 & 42,196 & 0,452 \\
\hline 20 & 42,480 & 0,465 \\
\hline Rata-rata & $\overline{\overline{\boldsymbol{X}}}=42,414$ & $\bar{S}=0,529$ \\
\hline
\end{tabular}

Rumus perhitungan $X$-bar Chart :

- Garis pusat (Central Line / CL)

$$
C L=\overline{\bar{x}}
$$

- Batas Kendali Atas (Upper Control Limit / UCL)

$$
U C L=\overline{\bar{x}}+A_{3} \bar{S}
$$

- Batas Kendali Bawah (Lower Control Limit / LCL)

$$
L C L=\overline{\bar{x}}-A_{3} \bar{S}
$$

Rumus Perhitungan S-Chart :

- Garis Pusat (Central Line / CL)

$$
C L=\bar{S}
$$

- Batas Kendali Atas (Upper Control Line / UCL)

$$
U C L=B_{4} \bar{S}
$$

- Batas Kendali Bawah (Lower Control Limit / LCL)

$$
L C L=B_{3} \bar{S}
$$

A3, B3 dan B4 merupakan faktor perhitungan untuk menghitung center line dan control limit. Nilai A3 adalah 0,606. Nilai B3 adalah 0,565. Nilai B4 adalah 1,435.

Dari perhitungan yang dilakukan akan diperoleh nilai untuk batas kendali atas, batas kendali bawah serta garis pusat atau central line yang kemudian dilanjutkan dengan membuat chart untuk peta kendali X-bar maupun peta kendali S.

Dari hasil perhitungan didapatkan peta kendali X-bar S Chart sebagai berikut : 

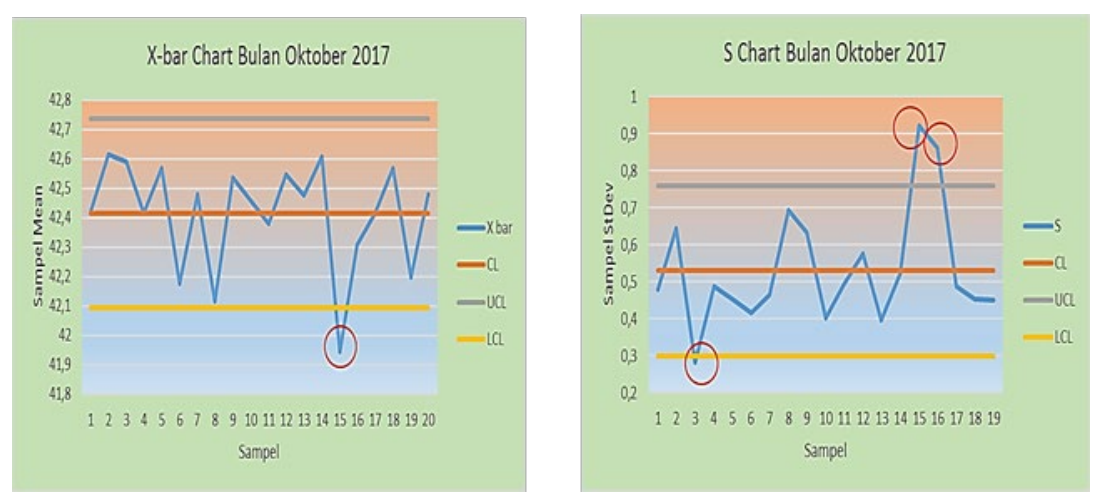

Gambar 1. X-bar S Chart Bulan Oktober 2017

Dari gambar 1 diketahui proses pengisian tepung bumbu kemasan 40 gram masih ada yang diluar batas pengendalian.

\subsection{Nilai Cp dan Cpk}

Perhitungan nilai $\mathrm{Cp}$ dan $\mathrm{Cpk}$ digunakan untuk mengetahui kemampuan suatu proses untuk menghasilkan produk yang sesuai dengan spesifikasi yaitu 40 sampai 43 gram.

- Rumus perhitungan $\mathrm{Cp}$

$$
C p=\frac{U S L-L S L}{6 \sigma}
$$

- Rumus perhitungan $\mathrm{Cpk}$

$$
C p k=\min \left(\frac{\mu-L S L}{3 \sigma}, \frac{U S L-\mu}{3 \sigma}\right)
$$

Dari hasil perhitungan didapatkan nilai $\mathrm{Cp}$ dan $\mathrm{Cpk}$ bulan Juli sebesar 0,814 dan 0,339. Nilai Cp dan Cpk bulan Agustus sebesar 0,794 dan 0,321. Nilai Cp dan Cpk bulan september sebesar 0,785 dan 0,321. Dan nilai Cp dan Cpk bulan Oktober sebesar 0,945 dan 0,369.

Setelah dilakukan perhitungan nilai $\mathrm{Cp}$ dan $\mathrm{Cpk}$, dilanjutkan dengan menggambar grafik kapabilitas proses. Dari grafik kapabiiitas proses dapat dilihat penyebaran data sampling serta batas atas dan batas bawah dari standar yang telah ditentukan. Dalam grafik kapabilitas proses dapat dilihat pola penyebaran data sampling yang diperoleh.

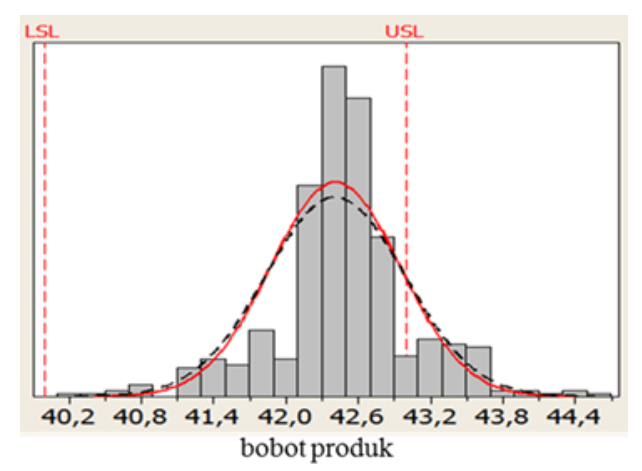

Gambar 2. Grafik Kapabilitas Proses Bulan Oktober 2017

\subsection{Nilai DPMO dan Nilai Sigma}

Nilai opportunities sebesar 3 disebabkan oleh adanya 3 tahapan proses yang memungkinan terjadinya defect pada proses pengemasan yaitu :

1. Transfer produk dari bintank ke hopper mesin single line

2. Setting scraper dan cup

3. Setting mesin 
Rumus perhitungan nilai DPMO dan nilai sigma adalah :

$$
\begin{gathered}
D P U=\frac{\text { total defect }}{\text { total unit }} \\
D P M O=\frac{\text { DPU } \times 1 \text { million }}{\text { Opportunities }}
\end{gathered}
$$

Contoh perhitungan nilai DPMO dan nilai sigma untuk bulan Oktober 2017.

\begin{tabular}{|c|c|c|c|c|}
\hline Sampel & $\begin{array}{c}\text { Jumlah } \\
\text { Sampling }\end{array}$ & $\begin{array}{c}\text { Jumlah } \\
\text { Defect }\end{array}$ & DPU & DPMO \\
\hline 1 & 25 & 3 & 0,120 & $40.000,000$ \\
\hline 2 & 25 & 8 & 0,320 & $106.666,667$ \\
\hline 3 & 25 & 4 & 0,160 & $53.333,333$ \\
\hline 4 & 25 & 4 & 0,160 & $53.333,333$ \\
\hline 5 & 25 & 3 & 0,120 & $40.000,000$ \\
\hline 6 & 25 & 0 & 0,000 & 0,000 \\
\hline 7 & 25 & 4 & 0,160 & $53.333,333$ \\
\hline 8 & 25 & 2 & 0,080 & $26.666,667$ \\
\hline 9 & 25 & 4 & 0,160 & $53.333,333$ \\
\hline 10 & 25 & 3 & 0,120 & $40.000,000$ \\
\hline 11 & 25 & 1 & 0,040 & $13.333,333$ \\
\hline 12 & 25 & 4 & 0,160 & $53.333,333$ \\
\hline 13 & 25 & 1 & 0,040 & $13.333,333$ \\
\hline 14 & 25 & 4 & 0,160 & $53.333,333$ \\
\hline 15 & 25 & 2 & 0,080 & $26.666,667$ \\
\hline 16 & 25 & 4 & 0,160 & $53.333,333$ \\
\hline 17 & 25 & 4 & 0,160 & $53.333,333$ \\
\hline 18 & 25 & 3 & 0,120 & $40.000,000$ \\
\hline 19 & 25 & 1 & 0,040 & $13.333,333$ \\
\hline 20 & 25 & 4 & 0,160 & $53.333,333$ \\
\hline Total & 500 & 63 & 2,520 & $840.000,000$ \\
\hline \multicolumn{3}{|c|}{ Rata - rata } & 0,126 & $42.000,000$ \\
\hline \multicolumn{3}{|c|}{ Rata - rata nilai sigma } & \multicolumn{2}{|c|}{3,222} \\
\hline
\end{tabular}

Tabel 2. Data Nilai DPMO dan Nilai Sigma Bulan Oktober 2017

Dari hasil perhitungan yang dilakukan dapat diketahui nilai DPMO dan nilai sigma bulan Juli sampai Oktober 2017. Nilai sigma diperoleh dengan mencocokan nilai DPMO dengan tabel konversi nilai DPMO terhadap nilai sigma berdasarkan konsep Motorola. Nilai DPMO bulan Juli sampai Oktober 2017 berturut-turut adalah 45.333,333, 50.666,667, 52.666,667, dan 42.000,000. Sedangkan nilai sigma bulan Juli sampai Oktober 2017 adalah 3,195, 3,132, 3,110, dan 3,222.

\subsection{Tabel 5 - Why}

Berdasarkan hasil analisis diketahui bahwa penyebab ketidakstabilan proses pengisian tepung bumbu kemasan 40 gram terdiri dari dua faktor, yaitu faktor mesin dan faktor manusia. 
Tabel 3. Tabel 5 - Why Faktor Mesin

\begin{tabular}{|c|c|c|c|c|c|c|}
\hline Faktor & Masalah & Why-1 & Why-2 & Why-3 & Why-4 & Why-5 \\
\hline \multirow{5}{*}{ Machine } & \multirow{2}{*}{$\begin{array}{l}\text { cup mesin } \\
\text { tidak terisi } \\
\text { sesuai } \\
\text { kapasitas }\end{array}$} & \multirow{2}{*}{$\begin{array}{c}\text { jarak antara } \\
\text { cup dan } \\
\text { scraper } \\
\text { renggang }\end{array}$} & \multirow[t]{2}{*}{$\begin{array}{c}\text { setting mesin } \\
\text { tidak pas }\end{array}$} & \multirow[t]{2}{*}{$\begin{array}{c}\text { operator } \\
\text { kurang paham } \\
\text { setting mesin }\end{array}$} & \multirow[t]{2}{*}{$\begin{array}{c}\text { karyawan baru } \\
\text { (PKWT) }\end{array}$} & $\begin{array}{c}\text { kurang } \\
\text { pelatihan } \\
\text { (coaching } \\
\text { senor) }\end{array}$ \\
\hline & & & & & & kurang training \\
\hline & \multirow{3}{*}{$\begin{array}{l}\text { kondisi mesin } \\
\text { tidak stabil }\end{array}$} & \multirow{3}{*}{ mesin error } & $\begin{array}{c}\text { setting mesin } \\
\text { hanya di awal } \\
\text { dan ganti roll } \\
\text { kemasan } \\
\end{array}$ & $\begin{array}{c}\text { tidak ada } \\
\text { jadwal setting } \\
\text { mesin }\end{array}$ & $\begin{array}{c}\text { jadwal setting } \\
\text { mesin belum } \\
\text { ditentukan }\end{array}$ & - \\
\hline & & & $\begin{array}{c}\text { maintenance } \\
\text { mesin } \\
\text { dilakukan saat } \\
\text { libur dan mesin } \\
\text { rusak }\end{array}$ & $\begin{array}{c}\text { belum ada } \\
\text { jadwal } \\
\text { maintenance } \\
\text { secara berkala }\end{array}$ & - & - \\
\hline & & & $\begin{array}{c}\text { maintenance } \\
\text { mesin } \\
\text { terhambat }\end{array}$ & $\begin{array}{c}\text { sparepart } \\
\text { mesin tidak } \\
\text { ada }\end{array}$ & stock habis & - \\
\hline
\end{tabular}

Tabel 4. Tabel 5 - Why Faktor Manusia

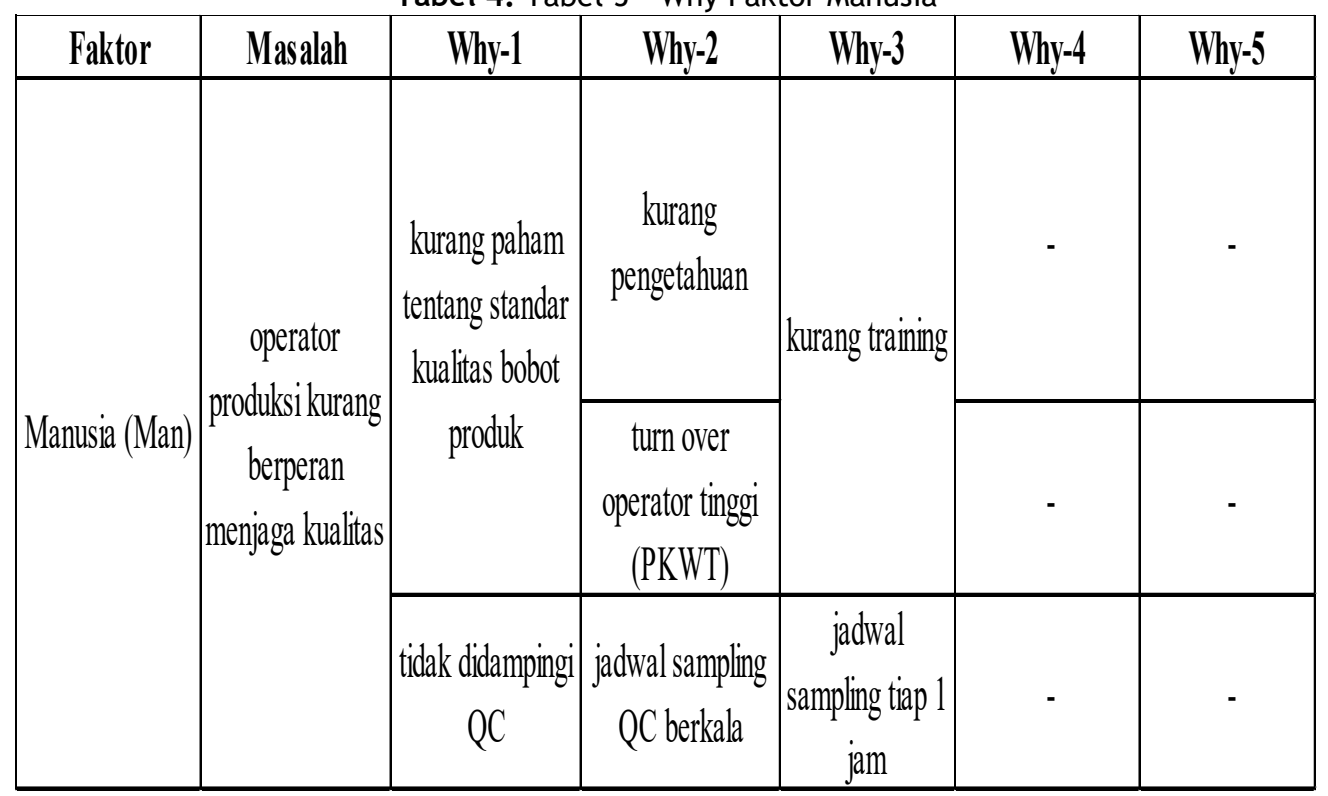

\subsection{Perbaikan yang dilakukan}

Untuk perbaikan di bagian mesin ditekankan pada setting mesin. Setting mesin dilakukan di awal produksi dan kontinyu dilakukan tiap 30 menit sekali jika pada saat pengecekan bobot produk tidak sesuai dengan standar atau spesifikasi yang telah ditentukan.

Perbaikan faktor manusia ditekankan pada operator produksi. Operator produksi dilibatkan dalam menjaga kualitas bobot produk tepung bumbu 40 gram dan sebelumnya telah diberi arahan 
oleh petugas QC. Sampling bobot tepung bumbu kemasan 40 gram yang biasanya dilakukan 1 jam sekali oleh personel QC diubah menjadi :

1. Pengecekan setiap 30 menit sekali yang dilakukan oleh operator produksi bagian pengemasan (filling)

Operator produksi setiap 30 menit sekali mengambil sampling tepung bumbu dan melakukan pengecekan bobot produk. Jika tidak sesuai dengan standar atau spesifikasi makan bisa langsung dilakukan setting mesin kembali.

2. Pengecekan setiap 1 jam sekali yang tetap dilakukan oleh personel QC yang kemudian ditulis di check sheet sampling penimbangan.

\subsection{Hasil Perbaikan}

Hasil perbaikan diketahui dengan jumlah defect yang menurun pada bulan November dan Desember menjadi $5,40 \%$ dan $4,60 \%$.

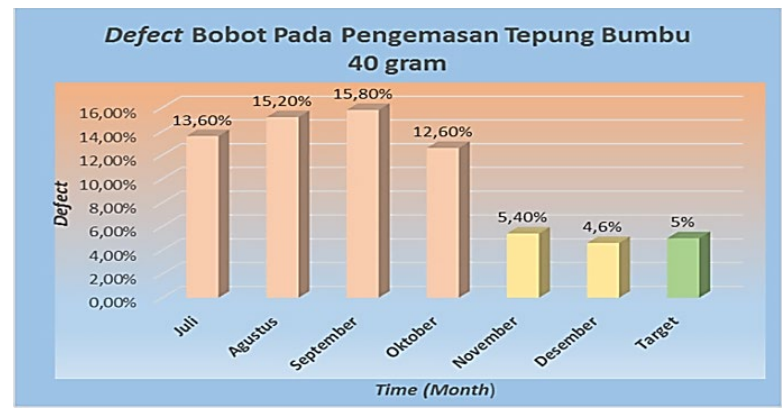

Gambar 3. Perbandingan Defect Sebelum dan Sesudah Perbaikan

\subsubsection{X-bar S Chart Bulan Desember 2017}

Tabel 5. Data Bulan Desember 2017

\begin{tabular}{|c|c|c|}
\hline Sampel & $\bar{x}$ & $S$ \\
\hline 1 & 42,294 & 0,600 \\
\hline 2 & 42,528 & 0,201 \\
\hline 3 & 42,532 & 0,275 \\
\hline 4 & 42,056 & 0,626 \\
\hline 5 & 42,116 & 0,534 \\
\hline 6 & 42,232 & 0,443 \\
\hline 7 & 42,180 & 0,668 \\
\hline 8 & 42,020 & 0,493 \\
\hline 9 & 42,396 & 0,490 \\
\hline 10 & 42,236 & 0,409 \\
\hline 11 & 42,396 & 0,354 \\
\hline 12 & 42,464 & 0,327 \\
\hline 13 & 42,380 & 0,587 \\
\hline 14 & 42,448 & 0,303 \\
\hline 15 & 41,956 & 0,540 \\
\hline 16 & 42,120 & 0,533 \\
\hline 17 & 42,405 & 0,427 \\
\hline 18 & 42,083 & 0,484 \\
\hline 19 & 42,083 & 0,602 \\
\hline 20 & 42,019 & 0,643 \\
\hline Rata - rata & $\overline{\overline{\boldsymbol{x}}}=42.200$ & $\overline{\boldsymbol{S}}=0,477$ \\
\hline
\end{tabular}



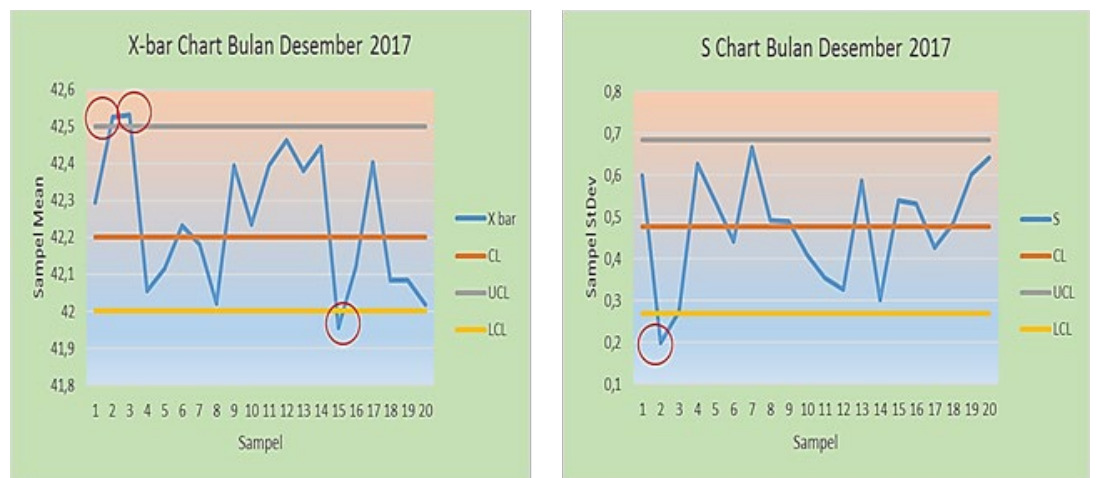

Gambar 4. X-bar S Chart Bulan Desember 2017

Dari gambar X-bar dan S Chart dapat diketahui proses pengisian tepung bumbu kemasan 40 gram di mesin single line masih ada yang diluar batas pengendalian, akan tetapi sudah mengalami penurunan jika dibandingkan dengan sebelum dilakukan perbaikan.

\subsubsection{Nilai Cp dan Cpk Bulan November dan Desember 2017}

Nilai $\mathrm{Cp}$ dan $\mathrm{Cpk}$ mengalami peningkatan setelah dilakukan perbaikan yang berarti kemampuan proses semakin baik. Nilai Cp dan Cpk pada bulan November 2017 sebesar 0,926 dan 0,475. Nilai Cp dan Cpk pada bulan Desember 2017 sebesar 1,119 dan 0,597.

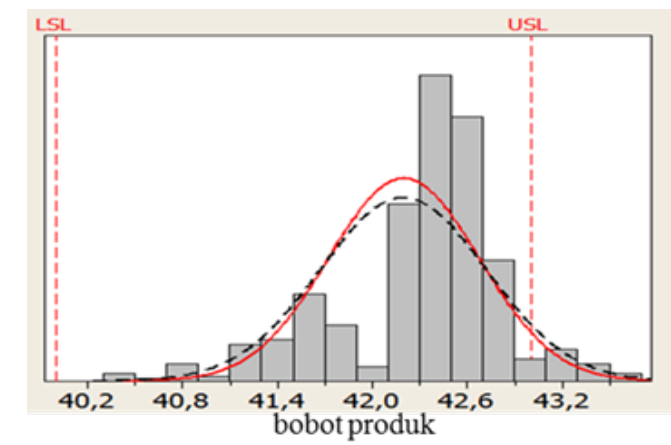

Gambar 5. Kapabilitas Proses Bulan Desember 2017

\subsubsection{Nilai DPMO dan Nilai Sigma Bulan November dan Desember 2017}

Setelah dilakukan perbaikan nilai DPMO mengalami penurunan dan nilai sigma meningkat. Nilai DPMO bulan November 2017 sebesar 18.000,00. Nilai DPMO bulan Desember 2017 sebesar 15.333,333. Sedangkan nilai sigma berdasarkan tabel konversi nilai DPMO terhadap nilai sigma berdasarkan konsep Motorola adalah 3,593 untuk bulan November 2017 dan 3,669 untuk bulan Desember 2017.

Tabel 6. Perbandingan Nilai DPMO dan Nilai Sigma Sebelum dan Sesudah Perbaikan

\begin{tabular}{|c|c|c|}
\hline Bulan & DPMO & Nilai Sigma \\
\hline Juli & $45.333,333$ & 3,195 \\
\hline Agustus & $50.666,667$ & 3,132 \\
\hline September & $52.666,667$ & 3,11 \\
\hline Oktober & $42.000,000$ & 3,222 \\
\hline November & $18.000,000$ & 3,593 \\
\hline Desember & $15.333,333$ & 3,669 \\
\hline
\end{tabular}


Tabel 7. Data Nilai DPMO dan Nilai Sigma Bulan November sampai Desember 2017

\begin{tabular}{|c|c|c|c|c|}
\hline Sampel & $\begin{array}{c}\text { Jumlah } \\
\text { Sampling }\end{array}$ & $\begin{array}{c}\text { Jumlah } \\
\text { Defect }\end{array}$ & DPU & DPMO \\
\hline 1 & 25 & 2 & 0,080 & $26.666,667$ \\
\hline 2 & 25 & 1 & 0,040 & $13.333,333$ \\
\hline 3 & 25 & 2 & 0,080 & $26.666,667$ \\
\hline 4 & 25 & 1 & 0,040 & $13.333,333$ \\
\hline 5 & 25 & 1 & 0,040 & $13.333,333$ \\
\hline 6 & 25 & 1 & 0,040 & $13.333,333$ \\
\hline 7 & 25 & 2 & 0,080 & $26.666,667$ \\
\hline 8 & 25 & 0 & 0,000 & 0,000 \\
\hline 9 & 25 & 2 & 0,080 & $26.666,667$ \\
\hline 10 & 25 & 0 & 0,000 & 0,000 \\
\hline 11 & 25 & 1 & 0,040 & $13.333,333$ \\
\hline 12 & 25 & 0 & 0,000 & 0,000 \\
\hline 13 & 25 & 3 & 0,120 & $40.000,000$ \\
\hline 14 & 25 & 1 & 0,040 & $13.333,333$ \\
\hline 15 & 25 & 0 & 0,000 & 0,000 \\
\hline 16 & 25 & 1 & 0,040 & $13.333,333$ \\
\hline 17 & 25 & 1 & 0,040 & $13.333,333$ \\
\hline 18 & 25 & 0 & 0,000 & 0,000 \\
\hline 19 & 25 & 2 & 0,080 & $26.666,667$ \\
\hline 20 & 25 & 2 & 0,080 & $26.666,667$ \\
\hline Total & 500 & 23 & 0,920 & $306.666,667$ \\
\hline \multicolumn{3}{|c|}{ Rata - rata } & 0,046 & $15.333,333$ \\
\hline \multicolumn{3}{|c|}{ Rata - rata nilai sigma } & \multicolumn{2}{|c|}{$\frac{1}{3,669}$} \\
\hline
\end{tabular}

Dari data pengukuran hasil perbaikan, dapat diketahui defect yang terjadi pada proses pengemasan tepung bumbu 40 gram mengalami perubahan. Perubahan yang terjadi adalah :

1. Defect mengalami penurunan

Defect pada bulan November sebesar $5,40 \%$ dan bulan Desember sebesar 4,60\%, lebih kecil dibandingkan dengan defect sebelum perbaikan yaitu 13,6\% (Juli), 15,20\% (Agustus), 15,80\% (September), 12,60\% (Oktober).

2. Nilai Cp dan Cpk mengalami perbaikan. Nilai Cp menjadi 0,926 (November) dan 1,19 (Desember) dari sebelumnya 0,814 (Juli), 0,794 (Agustus), 0,785 (September) dan 0,945 (Oktober). Hal ini menunjukkan kemampuan proses semakin baik.

3. DPMO mengalami penurunan menjadi 18.000 (November) dan $15.333,333$ (Desember) dari sebelumnya 45.333,333 (Juli), 50.666,667 (Agustus), 52.666,667 (September) dan 42.000 (Oktober).

4. Nilai sigma mengalami perubahan menjadi 3,593 (November) dan 3,669 (Desember) dari sebelumnya sebesar 3,195 (Juli), 3,132 (Agustus), 3,110 (September) dan 3,222 (Oktober).

\subsection{Proses Control}

Proses control yang dilakukan meliputi :

1. Pengaturan sampling penimbangan bobot produk

Pengaturan sampling meliputi :

a. Tiap 30 menit sekali sampling penimbangan bobot produk dilakukan oleh operator produksi. Jika bobot tidak sesuai tidak sesuai dapat langsung melakukan setting mesin dengan mengatur jarak antara meja cup dengan scraper.

b. Tiap 1 jam sekali sampling penimbangan bobot produk dilakukan oleh personel QC in-line.

2. Check Sheet sampling penimbangan

Data sampling penimbangan dicatat di check sheet sampling penimbangan agar data terekam agar dapat digunakan sebagai laporan dan perbaikan lanjutan. 


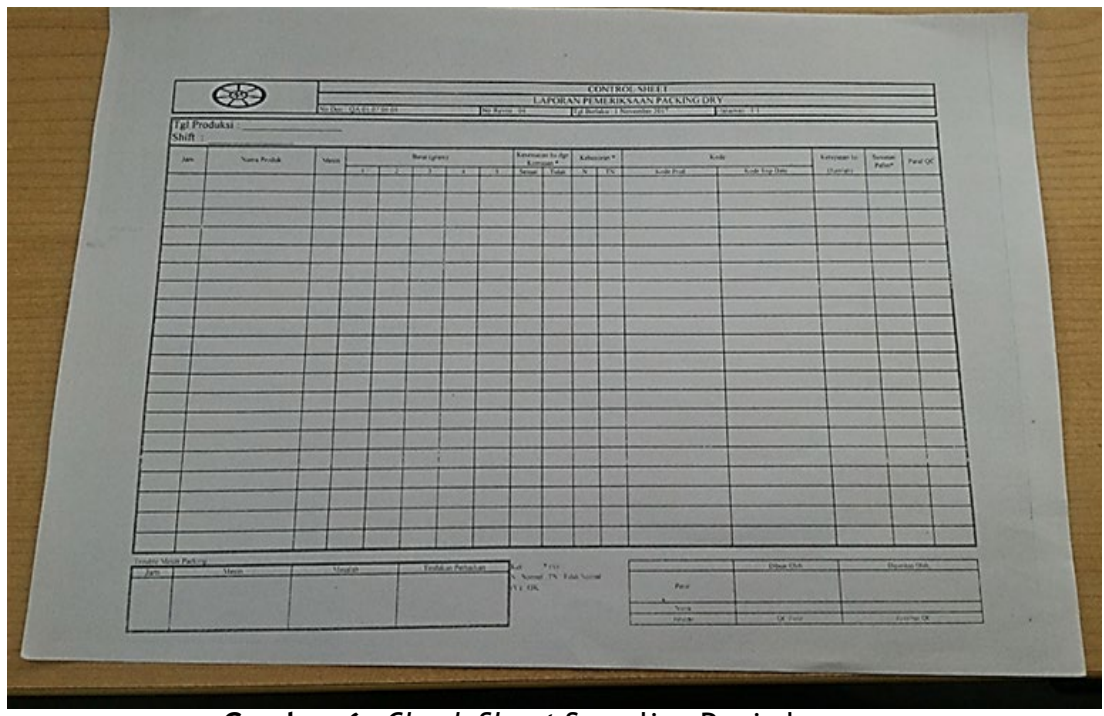

Gambar 6. Check Sheet Sampling Penimbangan

\section{Simpulan}

Dengan menerapkan metode DMAIC dapat diketahui ketidakstabilan proses pengisian, pengukuran proses pengisian, menganalisis penyebab ketidakstabilan proses pengisian, melakukan perbaikan dalam proses pengisian serta melakukan control terhadap proses pengisian setelah dilakukan perbaikan. Dari hasil penelitian diketahui proses pengisian tepung bumbu kemasan 40 gram menjadi lebih baik setelah dilakukan analisis dan perbaikan berdasarkan metode DMAIC.

\section{References}

1. Badri, Ahmad, Analisis Pengurangan Jumlah Produk Cacat Pada Proses Painting Untuk Panel CTR Console 83440-TBN-T210-20 Dengan Menggunakan Pendekatan Six Sigma Di PT Sanwa Screen Indonesia, Skripsi, President University, 2017.

2. Gaspersz, Vincent dan Avanti Vontana, Lean Six Sigma for Manufacturing and Service Industries, Vinchistro Publication, Bogor, 2015.

3. http://www.eriskusnadi.wordpress.com on 9 Juni 2012.

4. Mitra, Amitava, Fundamentals of Quality Control and Improvement, A Jhon Wiley \& Sons, Canada, 2008.

5. Pande, Peter S, Robert P. Neuman dan Roland R. Cavanagh, The Six Sigma Way, Andi, Yogyakarta 2002.

6. Tague, N. R., The Quality Toolbox (2th edition), Milwaukee, Winconsin, 2005.

7. Tannady, Hendy, Pengendalian Kualitas, Graha Ilmu, Yogyakarta, 2015.

8. Tjiptono, Fandy, Strategi Pemasaran, Andi Offset, Yogyakarta, 2012.

9. Sutalaksana, Iftikar Z, Teknik Tata Cara Kerja, ITB, Bandung, 1979. 